\title{
Factors Influencing Teachers' Performance in Junior High School
}

\author{
Usfandi Haryaka1, Hasbi Sjamsir ${ }^{2 *}$ \\ ${ }^{1}$ Associate Professor, College of Education, Mulawarman University, Samarinda-Indonesia \\ ${ }^{2}$ Associate Professor, College of Education, Mulawarman University, Samarinda-Indonesia \\ ${ }^{2 *}$ Corresponding author: Hasbi Sjamsir. hasbisjamsir@fkip.unmul.ac.id
}

Article History: Received: 10 November 2020; Revised 12 January 2021 Accepted: 27 January

2021; Published online: 5 April 2021

\begin{abstract}
The study aims to determine whether work motivation affects teacher performance, discipline influences teacher performance, and teacher interpersonal communication affects teacher performance. Also, this research explores the prominent factors that influence teacher performance. This research was conducted at Samarinda Middle School with a sample of 60 randomly selected teachers from six Junior High Schools in Samarinda. The data were collected using a questionnaire, followed by interviews with five teacher representatives from each school. Furthermore, the data were analyzed by path analysis. The findings indicate that: (1) work motivation had a direct positive effect on teacher performance, (2) work discipline had a direct positive influence on teacher performance, (3) teacher interpersonal communication had a direct effect on teacher performance, and (4) the most dominant influential factor on teacher performance was teachers' interpersonal communication.
\end{abstract}

Keywords: teacher performance, work motivation, work discipline, interpersonal communication.

\section{Introduction}

The quality of education at schools is largely determined by the performance of teachers in the learning process. The statement implies that learning effectiveness can be achieved when the teachers can carry out tasks with full responsibility and dedication. Teacher performance is reflected in the teachers' quality in planning learning, evaluating learning outcomes, and implementing counseling and training.

Teachers are the most pivotal aspect of education and are considered those who play essential roles in attaining educational goals. These goals are a reflection of education quality. Teachers' existence in completing tasks and responsibilities cannot be separated from internal influences or external factors that affect teacher performance.

Low teacher performance will have an impact on teacher work productivity. This fact shows the low level of teachers' working motivation. The teachers' motivation is closely related to what they desire, hope, and achieve. Motivation will affect teachers' behavior and attitudes at work, whether as lazy, indifferent, enthusiastic or determined individuals despite challenges and pressures. The current era where the flow of information and change is rapid and complex requires teachers not only to have a sufficient set of knowledge and abilities but also to possess strong work motivation. Hence, their work productivity can increase.

Work motivation is the motivation or ability of the teachers to do their work. Teacher work motivation can be high or low. High or low teacher motivation is what can affect teacher performance in completing their work. Many ways are available to increase teacher work 
motivation, such as providing financial and non-financial incentives. For example, teachers have opportunities for self-development to pursue higher study or training.

The work productivity of teachers is reflected through their behavior in carrying out their tasks. For those with low work productivity, such teachers often go home early, are late for class, and in finishing their tasks, often engage in other activities besides teaching and learning during class hours, such as playing chess or playing cards. Furthermore, students are given the task of copying on the board while teachers chat during class hours, relax at work, and many other inappropriate activities. The decrease in teacher productivity level is also reflected in the decreased percentage of teacher attendance at school and in the classroom. Also, teacher competence in the learning development has not increased significantly; their creativity does not rise; they also protest and overlook all existing policies.

High productivity teachers are reflected on their behaviors, such as being passionate in teaching, arriving early at school, entering class early, finishing tasks on time, guiding students, actively encouraging students in school activities, possessing high responsibility and creativity, and having initiative and not waiting for orders from the school principal.

Teacher performance is one of the significant elements of work productivity. If a teacher has excellent performance, then she will achieve high work productivity. On the other hand, if a teacher shows low performance and cannot meet the desired requirements, she will most likely have low work productivity. Furthermore, discipline is another factor that can also improve teacher performance.

According to Rivai cited in Ahmad Susanto (2016), a work discipline is a tool used by managers to communicate with employees. They are willing to change their behavior to increase their awareness and willingness to comply with all organizational regulations and applicable social norms.

A discipline is a form of self-control and regular implementation. It shows the level of sincerity of teamwork in an organization. An individual has a high work discipline if he abides by the principle and is responsible for the assigned tasks.

To have and be able to meet the demands mentioned above, teachers should obtain sustainable and structured training. Schools should conduct evaluations on the teachers' performance in carrying out their duties. Hence, it is clear what aspects need to be fostered. Also, interpersonal communication, which is performed between fellow teachers and all school members should be well established because if not, the training will not work effectively. Thus, work discipline, work motivation, and interpersonal communication are highly influential on teachers' success in achieving their educational goals.

Communication, particularly effective interpersonal communication, is a foundation for the success of an organization. However, the reality in the field shows that communication both vertically and horizontally has not been carried out optimally. They seem to communicate from the surface, but in reality, most of what has been communicated does not occur. It affects teacher performance.

Munawarah (2013) found in her study the motivation of students in Jombang Vocational school that students learning styles affected their motivation. Also, Rizali Irawan (2103) conducted a study about the relationship between interpersonal communication and work motivation with librarians' performance in East Kalimantan province. It was found that a significant relationship between interpersonal communication and employee performance occurred. It means that the higher the interpersonal communication, the higher the performance of librarians in the East Kalimantan Government Library Board. The result showed a significant relationship between motivation and employee performance. It could indicate that the higher the work motivation, the higher the teacher's performance.

Rojifah Dinul Maulah (2016) studied the effect of interpersonal communication on school principals' work and work motivation on the performance of teachers in private junior 
secondary schools in the Tandes. Surabaya. It was concluded that the principals' interpersonal communication and work motivation influenced teachers' performance.

Furthermore, research conducted by Rizali Irawan (2013) on the relationship of interpersonal communication and work motivation with the performance of librarians in East Kalimantan province found that there was a significant relationship between interpersonal communication with employee performance and the relationship between motivation and employee performance.

Abdull Sukor (2008) conducted a study of 110 randomly selected secondary schools in Kedah and Perlis. The sample was a total of 86 schools, with $78 \%$ of respondents. Correlation analysis shows that (a) procedural fairness had a significant positive correlation with employee performance; (b) work motivation had a significant positive correlation with employee performance, and (c) school academic achievement had a significant positive correlation with employee performance.

Haryaka (2018) stated that interpersonal communication had a direct positive effect on lecturer performance. Simba (2016) found that discipline had a positive relationship with academic performance in eighth-grade students of the Muhoroni Sub-County Public Elementary School, Kenya. A study by Simba also showed that academic performance increased with the increasing levels of discipline.

Based on the findings from the research above, there was a gap of studies to prove the results of research conducted on the influence of teacher work discipline, teacher work motivation, and teacher interpersonal relationships on teacher performance. Furthermore, teachers' work discipline, work motivation, and interpersonal communication need to be further investigated, especially regarding the most influential factors determining teacher performance and the sequence influencing these three factors on teacher performance. Therefore, this research was conducted to investigate the factors that influence teacher performance.

\section{Literature Review \\ Teacher Performance}

Work performance is defined as an ability based on knowledge, attitudes, skills, and motivation in producing something.

According to Mulyasa (2013), performance is shown by an individual's appearance, deeds, and work achievements as an accumulation of knowledge, skills, values, and attitudes.

Wibowo (2007) defines performance as a result of work with a strong relationship with the organization's strategic goal, customer satisfaction, and contribution to the economy.

From various definitions of performance above, it can be concluded that performance is an individual's work performance. Work performance is the final result of an activity completed by an individual to achieve a goal.

Teacher performance has precise specifications. Teacher performance can be seen and measured based on the specifications or competency criteria of each teacher. Djaman Satari in Khusnul Wardan (2011) suggested that teacher performance indicators are in the form of quality of learning. While, Suhaimi, Akbar, Sjamsir (2019) stated that teacher performance has a huge influence and contribution to the quality of education. In this case, teachers strongly influence this quality in compiling instructional designs, mastering teaching methods, and using them according to the nature of student learning activities, interacting with students who lead to high motivation to feel joy in learning activities. Mastering materials and employing learning resources to generate active learning processes through the development of process skills recognize students' differences. Hence, teachers can provide learning guidance, assess the learning process and outcomes, provide feedback to students, and design remedial learning programs teachers strongly influence this quality in compiling instructional designs, mastering teaching methods, and using them according to the nature of student learning activities, 
interacting with students who lead to high motivation to feel joy in learning activities. Mastering materials and employing learning resources to generate active learning processes through the development of process skills recognize students' differences. Hence, teachers can provide learning guidance, assess the learning process and outcomes, provide feedback to students, and design remedial learning programs.

Permendiknas No. 41 of 2007 regarding Standard Process for Secondary Education Units outlined the teachers' workload includes the main activities: planning and implementing lessons, assessing learning outcomes, guiding and training students, and carrying out additional tasks.

From several definitions above, it can be concluded that the definition of teacher performance is the result of work performance carried out by a teacher based on the ability to manage teaching and learning activities, including lesson planning and implementation, lesson evaluation, and nurturing interpersonal relationships with students.

\section{Factors Affecting Teacher Performance}

Several factors determine the level of teacher performance, including work discipline, work motivation, and interpersonal relationships with fellow teachers.

\section{Work Discipline}

Barnawi (2012) stated that work discipline is one of the necessary internal factors to be considered in efforts to enhance teacher performance. The teacher work discipline is closely related to compliance in implementing school regulations. Neglected teacher work discipline will become a negative work culture that will reduce teacher performance in organizing the learning process.

According to Sinambela in Barnawi (2012), the nature of discipline is adherence to rules or orders set by an organization. Also, Sulistriyani in Barnawi (2012) argued that discipline is an act of management to encourage members of an organization to meet its various regulations, including code of conduct, compliance of members, sanctions for offenders. From the literature review, it can be concluded that the purpose of the work discipline is vital to achieving goals to support task implementation. Without awareness to follow predetermined rules, it is impossible to reach the maximum teaching target.

Meanwhile, Singodimedjo in Barnawi (2012) stated that external factors affected employee disciplines, such as compensation, exemplary role model, guideline rules, leaders' courage in taking action, supervision, attention to employees, and discipline habits. Simba's research showed that discipline had a positive relationship with the academic performance of eighth-grade students of the Muhoroni Sub-County Public Elementary School, Kenya. Also, it found that academic performance rose with increasing levels of discipline.

Ehiane's research (2014) also found that $70 \%$ of respondents believed that school discipline management had an impact on student academic achievement, discipline affected student academic achievement, and time management compliance affected student academic achievement. Haryaka (2018) also found that interpersonal communication had a direct positive effect on lecturer performance.

From the literature and results of the research above, it can be concluded that the implementation of work discipline was employee compliance during working hours, workers' adherence with orders from the leaders and rules and regulations, and working by following the specified work methods.

\section{Work motivation}

Husaini Usman (2009) explains that motivation is the desire to do something, while the motive is the need, wish, desire, or impulse. Motivation is the desire found in an individual who stimulates it to take action, or motivation is the basis for someone to behave. 
According to Schunk (2011), motivation is the process of initiating and sustaining activities that will be directed towards achieving goals. Work motivation can be defined as the desires or needs that lie behind an individual to encourage them to work.

Based on these experts' statements, it can be concluded that motivation is an internal condition that encourages individuals to complete certain activities to reach goals.

\section{Interpersonal Communication}

Humans are living creatures that can be seen from two sides, biological and social. The characteristics of social life require each individual to establish a relationship with one another. Hence, a mutual bond, a reciprocal pattern of relationships or interpersonal relationships, is built.

DeVito (2011) explains that interpersonal communication occurs between two people with a definite relationship. This definition reveals that it is almost impossible for communication to occur between two or more people who do not know each other. Interpersonal communication is a relationship that, if extended, can include small groups or work partners.

Brent D. Ruben in Muhammad (2011) shows that human communication is a process through which individuals in relationships, groups, organizations, and society create, transmit, and use the information to coordinate their environment and others.

Suranto (2011) states that interpersonal communication, in general, is the interaction carried out by one person to another in all situations and all walks of life, giving rise to happiness and satisfaction for both parties. Whereas interpersonal relations in specific is the interaction carried out by one person to others in work situations intending to change the excitement and productive work activities.

Mead in Alo Liliweri (2014) argues that interpersonal communication is where each individual can monitor actions against other people or the surrounding community as signs that he is performing a cognitive process. Palomero (in Paula, 2000) states that besides interpersonal communication, social skills consider empathy and solidarity in professional performance. It will also involve being emotional elsewhere, recognizing emotions, and mobilizing various actions that promote solidarity at various levels of the educational community.

Haryaka (2018) finds that interpersonal communication had a direct positive effect on lecturer performance. Navy O'Reilly and Robert's research in Fitrina Afrianti strongly supports that a relationship between the quality and quantity of communication with organizational performance occurs. Communication, especially effective interpersonal communication, is known as one of the bases for its success. Suranto posits that there are several characteristics of interpersonal relationships, namely close to each other, need each other, have patterns of interpersonal relationships and cooperation.

\section{Method}

The method used in this study is a survey method. The population in this study were all junior high school teachers in Samarinda City. The sample was 60 randomly selected Samarinda junior high school teachers.

Table 1. Research Sample

\begin{tabular}{|l|l|c|}
\hline No & \multicolumn{1}{|c|}{ School } & Total sample \\
\hline 1 & SMPN 1 Samarinda & 10 \\
\hline 2 & SMPN 4 Samarinda & 10 \\
\hline 3 & SMPN 5 Samarinda & 10 \\
\hline 4 & SMPN 7 Samarinda & 10 \\
\hline
\end{tabular}




\begin{tabular}{|l|c|c|}
\hline 5 & SMPN 22 Samarinda & 10 \\
\hline 6 & SMPN 24 Samarinda & 10 \\
\hline \multicolumn{2}{|c|}{ Total } & 60 \\
\hline
\end{tabular}

The data were collected through questionnaires. Furthermore, interviews were conducted with several representative respondents, 5 respondents for each school to clarify their answers to each variable on the questionnaire.

The questionnaire developed by the research team included a Work Motivation questionnaire with 35 statements, a Work Discipline questionnaire with 36 statements, an Interpersonal Communication questionnaire with 37 statements, and a Teacher Performance questionnaire with 35 statements.

Instrument trials were carried out on 30 junior high school teachers in Samarinda who were not the research samples. The validity of the items in the questionnaire was tested using the Product Moment correlation formula from Person by comparing the r-count with the r-table at the significance level $\propto=0.05$. If the obtained $r$-count is greater than $r$-table $=0.361$, the questionnaire item is declared valid. And from the results of the validity of the questionnaire, it was obtained that a valid questionnaire was a Work Motivation questionnaire with 31 statements, a Work Discipline questionnaire with 30 statements, 31 statements for Interpersonal Communication, and a Teacher Performance questionnaire with 31 statements. Meanwhile, the reliability of the questionnaire was tested using the Alpha efficiency formula from Cronbach, namely:

$\alpha=\mathrm{k} /(\mathrm{k}-1)\left[1-\left(\sum \mathrm{S} \_\mathrm{t} \wedge 2\right) /\left(\mathrm{S} \_\mathrm{t}^{\wedge}{ }^{\wedge} 2\right)\right]$

With $\alpha=$ the reliability coefficient of the statement items

$\mathrm{k}=$ many valid items

$\sum \mathrm{S}_{-} \mathrm{t}^{\wedge} 2=$ the number of variants in the score of the statement items

$\mathrm{S} \_\mathrm{t} \wedge 2=$ total variant

From the statistical calculations, the results of the reliability test on the Work Motivation questionnaire, the Work Discipline questionnaire, the Interpersonal Communication questionnaire, and the Teacher Performance questionnaire are respectively obtained as in the following table.

Table 2. Instrument Reliability

\begin{tabular}{|l|l|c|c|}
\hline No & \multicolumn{1}{|c|}{ Questionnaire } & Cronbach's Alpha & Category \\
\hline 1 & Work Motivation & $0.895>0,7$ & high \\
\hline 2 & Work Discipline & $0.885>0,7$ & high \\
\hline 3 & Interpersonal Communication & $0.882>0,7$ & high \\
\hline 4 & Teacher Performance & $0.917>0,7$ & high \\
\hline
\end{tabular}

\section{Data Analysis}

Path analysis was employed in this study. An assumption test was held in the path analysis, such as the normality test and linearity test. Furthermore, the path coefficient of each exogenous variable was searched for its endogenous variable.

The path analysis used in this study is based on the research design described in the following path diagram model. 


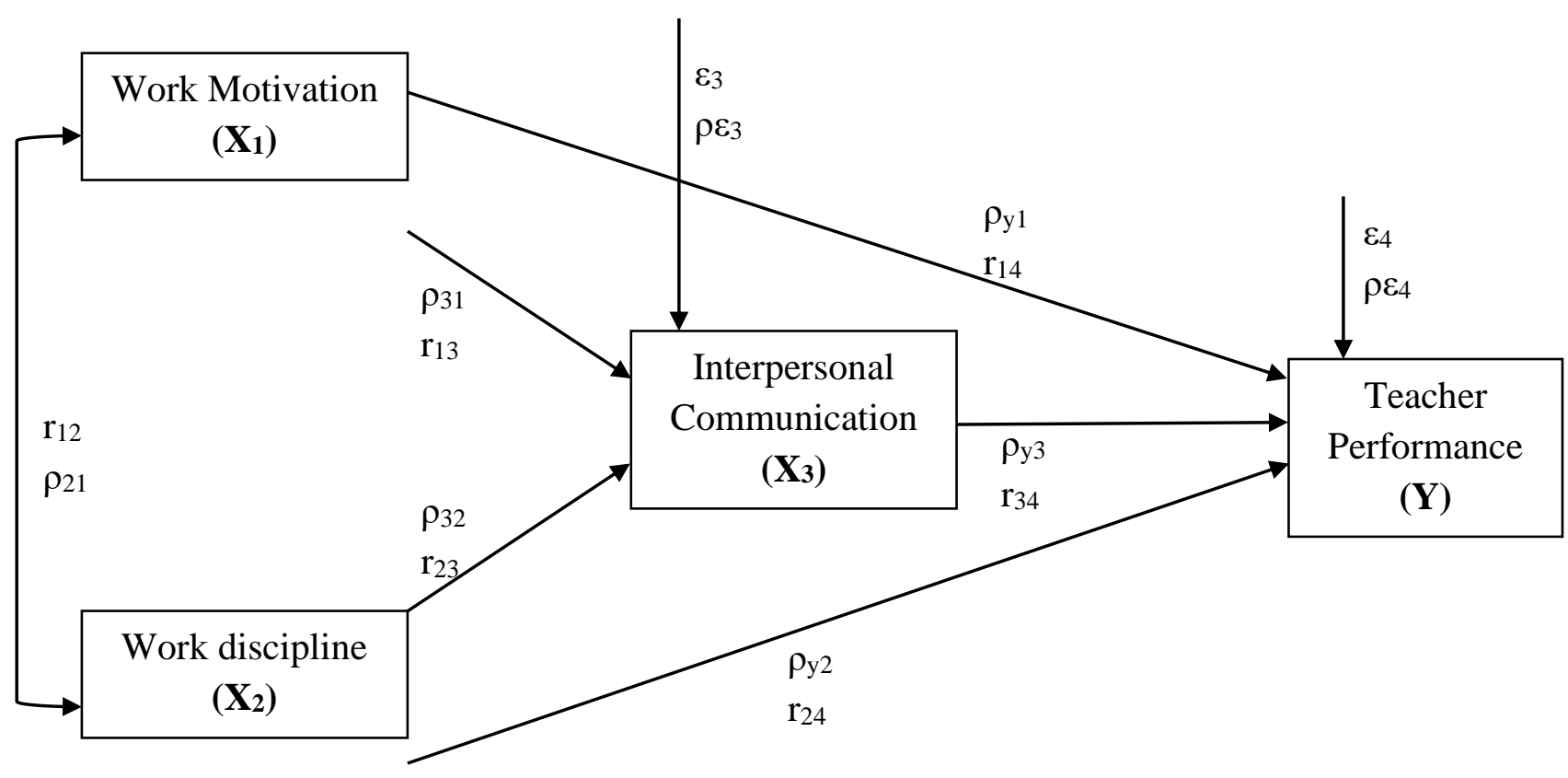

Figure 1. Path Model Diagram

In this study, the exogenous variables were work motivation, work discipline and interpersonal communication, while the endogenous variables were teacher performance. rij $=$ the correlation coefficient between the $i$-th variable and the $j$-th variable $\rho \mathrm{ji}=$ path coefficient from the ith variable to the $\mathrm{j}$-variable

To find the path coefficient $\rho j \mathrm{i}$ is to use the solution of the following system of equations:

$\mathrm{r} 12=\rho 21$

$\mathrm{r} 13=\rho 21+\rho 21 \mathrm{r} 12$

$\mathrm{r} 23=\rho 31 \mathrm{r} 12+\rho 32$

$\mathrm{r} 14=\rho 41+\rho \mathrm{y} 2 \mathrm{r} 12+\rho \mathrm{y} 3 \mathrm{r} 13$

r24 $=\rho y 1$ r $12+\rho y 2+\rho y 3$ r 23

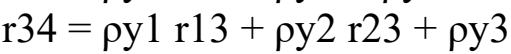

The data needed in this research are data from work motivation, work discipline, interpersonal communication, and teacher performance. After the data is collected then look for the correlation coefficient between variables, namely r12, r13, r14, r23, r24, and r34 using the Product Moment correlation formula and then look for the path coefficients $\rho 21, \rho 31, \rho y 1, \rho 32$, py2, and $\rho y 3$.

The Product Moment correlation formula that is intended is as follows.

$r_{x y}=\frac{N \sum X Y-\left(\sum X\right)\left(\sum Y\right)}{\sqrt{\left(\mathrm{N} \sum \mathrm{X} 2-(\Sigma \mathrm{X}) 2\right)\left(\mathrm{N} \sum \mathrm{Y} 2-\left(\sum \mathrm{Y}\right) 2\right)}}$

\section{The Results of Study}

\section{Research Data Description}

Based on data from research conducted on four variables: work motivation (X1), work discipline (X2), and interpersonal communication (X3) as exogenous variables while performance $(\mathrm{Y})$ as an endogenous variable, the following data were obtained:The operational definitions of the four variables of this study can be explained as follows.

Work motivation is an encouragement that arises from a person to carry out a job, with indicators (1) skills at work; (2) persistence in doing work; (3) efforts to improve the quality 
of work; (4) work capacity-building efforts; (5) a sense of pride in the work; and (6) expectations of work results.

Work discipline is the implementation of employee compliance in working with indicators (1) employee compliance during working hours, (2) employee compliance with orders from the leadership; (3) obedience to wearing clothes and attributes at work; and (4) compliance with predetermined ways of working.

Interpersonal communication is the interaction between a person and another in a work situation with indicators (1) openness; (2) empathy; (3) equality of perception; (4) vertical relationship with the leadership; and (5) horizontal relationships with peers.

Teacher performance is the teacher's performance in completing tasks and responsibilities based on their abilities and skills with indicators (1) pedagogic ability; (2) professional skills; (3) social skills; and (4) personality abilities.

Table 2. Data Description

\begin{tabular}{|l|l|l|l|l|}
\hline \multicolumn{1}{|c|}{ Variable } & \multicolumn{1}{|c|}{ Mean } & Std. Deviation & Minimum & Maximum \\
\hline Work Motivation & 120.80 & 9.159 & 100 & 141 \\
\hline Work Discipline & 123.17 & 10.210 & 99 & 146 \\
\hline Interpersonal Communication & 123.65 & 10.591 & 100 & 146 \\
\hline Teacher Performance & 138.38 & 7.094 & 120.66 & 151.00 \\
\hline
\end{tabular}

Furthermore, the data needs to be clarified whether the respondents answered questions thoughtfully or not. It was due to other factors, so the data were suspected not as valid as expected. The results of interviews with randomly selected 30 from six different schools found the data as presented in the following table.

Table 3. Results of Interviews with Respondents

\begin{tabular}{|l|c|l|}
\hline \multicolumn{1}{|c|}{ Variable } & \multicolumn{1}{|c|}{$\begin{array}{c}\text { Answers of } \\
\text { Respondents }\end{array}$} & Percentage \\
\hline Work Motivation & 26 & $86.67 \%$ \\
\hline Work Discipline & 27 & $90.00 \%$ \\
\hline Interpersonal Communication & 28 & $93.33 \%$ \\
\hline Teacher Performance & 26 & $86.67 \%$ \\
\hline
\end{tabular}

Based on the interview results, it can be concluded that the data from work motivation, work discipline, work communication, and teacher performance were relatively valid because the respondents answered the questionnaire with their actual condition. Also, the remaining percentage could be revealed in this study because the respondent did not answer some. 


\section{Assumption Test}

\section{Normality Test}

The data were tested using the Kolmogorov-Smirnov normality test, which compared the absolute value of $\mathrm{D}_{\text {count }}$ with $\mathrm{D}_{\text {table. }}$. If $\mathbf{D}_{\text {count }}<\mathbf{D}_{\text {table, }}$, it can be concluded that the data came from the normal distribution. The normality test on each variable was displayed in the following table

Table 4. Result of Normality Test

\begin{tabular}{|l|l|l|l|l|}
\hline \multicolumn{1}{|c|}{ Variable } & D $_{\text {count }}$ & \multicolumn{1}{c|}{ D table } & Comparison & Assumption \\
\hline Work Motivation $\left(\mathrm{X}_{1}\right)$ & 0.082 & 0.175 & $0.082<0.175$ & Normal \\
\hline Work Discipline $\left(\mathrm{X}_{2}\right)$ & 0.075 & 0.175 & $0.075<0.175$ & Normal \\
\hline Int. Communication $\left(\mathrm{X}_{3}\right)$ & 0.066 & 0.175 & $0.066<0.175$ & Normal \\
\hline Teacher Performance $(\mathrm{Y})$ & 0.119 & 0.175 & $0.119<0.175$ & Normal \\
\hline
\end{tabular}

\section{Linearity Test}

This test was used to determine whether the multiple linear regression model was suitable. Linearity test was applied to check whether the linearity obtained $\operatorname{sig}<\alpha(0.05)$. Furthermore, it was concluded that the relationship between the two variables was linear. The linearity data relationship between variables was depicted in the following table.

Table 5. Result of Linear Data

\begin{tabular}{|l|l|l|l|l|}
\hline \multicolumn{1}{|c|}{ Variable Relation } & \multicolumn{1}{c|}{ Equation } & $F$ Value & Sig Value & Linearity \\
\hline $\mathrm{X}_{2}$ and $\mathrm{X}_{1}$ & $\mathrm{X}_{2}=80.46+0.35 \mathrm{X}_{1}$ & 22.27 & 0.000 & Linear \\
\hline $\mathrm{X}_{3}$ and $\mathrm{X}_{1}$ & $\mathrm{X}_{3}=38.93+0.70 \mathrm{X}_{1}$ & 61.34 & 0.000 & Linear \\
\hline $\mathrm{X}_{3}$ and $\mathrm{X}_{2}$ & $\mathrm{X}_{3}=48.66+0.35 \mathrm{X}_{2}$ & 126.77 & 0.000 & Linear \\
\hline $\mathrm{Y}$ and $\mathrm{X}_{1}$ & $\mathrm{Y}=95.94+0.35 \mathrm{X}_{1}$ & 14.92 & 0.001 & Linear \\
\hline $\mathrm{Y}$ and $\mathrm{X}_{2}$ & $\mathrm{Y}=95.75+0.34 \mathrm{X}_{2}$ & 38.22 & 0.000 & Linear \\
\hline $\mathrm{Y}$ and $\mathrm{X}_{3}$ & $\mathrm{Y}=87.97+0.40 \mathrm{X}_{3}$ & 92.36 & 0.000 & Linear \\
\hline
\end{tabular}

\section{Hypotheses Test}

\section{Correlation Test}

The results of the correlation among the research variables are displayed in the following table.

Table 6. Correlation among Variables

\begin{tabular}{|c|c|c|c|c|}
\hline Variable & $\mathbf{X}_{\mathbf{1}}$ & $\mathbf{X}_{\mathbf{2}}$ & $\mathbf{X}_{\mathbf{3}}$ & $\mathbf{Y}$ \\
\hline $\mathrm{X}_{1}$ & 1.00 & 0.32 & 0.59 & 0.45 \\
\hline $\mathrm{X}_{2}$ & 0.32 & 1.00 & 0.77 & 0.49 \\
\hline $\mathrm{X}_{3}$ & 0.59 & 0.77 & 1.00 & 0.62 \\
\hline $\mathrm{Y}$ & 0.45 & 0.49 & 0.62 & 1.00 \\
\hline
\end{tabular}


Furthermore, based on the statistical test, the path coefficient was obtained as follows.

Table 7. Path coefficient

\begin{tabular}{|l|l|l|l|l|}
\hline Relation among variables & \multicolumn{1}{|c|}{$\begin{array}{c}\text { Path } \\
\text { coefficient }\end{array}$} & $\mathbf{t}$ count & $\mathbf{t}$ table & Conclusion \\
\hline $\mathrm{X}_{1}$ and $\mathrm{X}_{3}$ & $\rho_{31}=0.458$ & 4.029 & 1.67 & Significant \\
\hline $\mathrm{X}_{2}$ and $\mathrm{X}_{3}$ & $\rho_{32}=0.431$ & 3.784 & 1.67 & Significant \\
\hline $\mathrm{X}_{1}$ and $\mathrm{Y}$ & $\rho_{\mathrm{y} 1}=0.138$ & 2.146 & 1.67 & Significant \\
\hline $\mathrm{X}_{2}$ and $\mathrm{Y}$ & $\rho_{\mathrm{y} 2}=0.215$ & 2.216 & 1.67 & Significant \\
\hline $\mathrm{X}_{3}$ and $\mathrm{Y}$ & $\rho_{\mathrm{y} 3}=0.412$ & 3.341 & 1.67 & Significant \\
\hline
\end{tabular}

The correlation coefficient and path coefficient obtained from research data can be illustrated in the following figure.

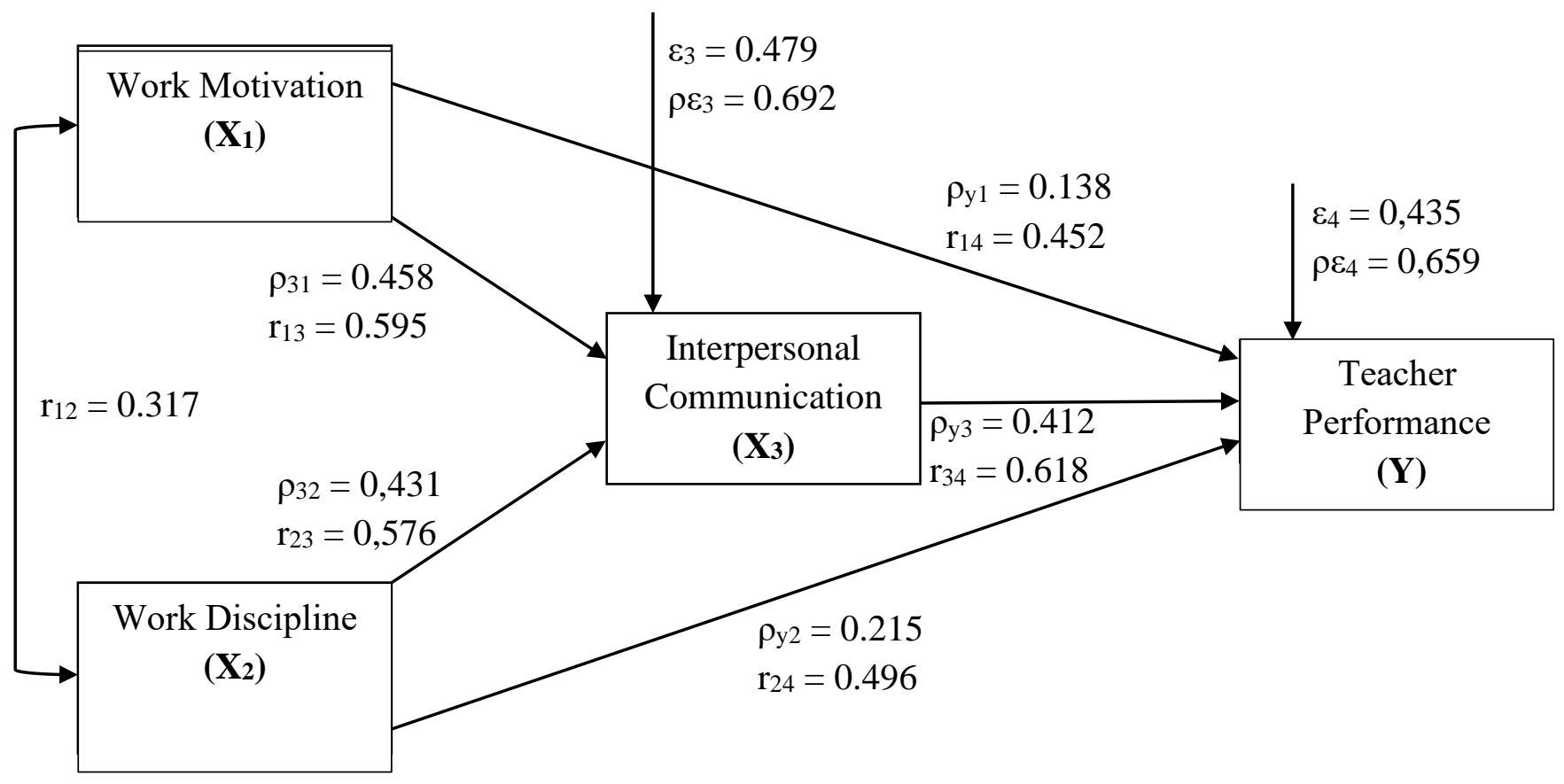

Figure 2. Research Path Model Diagram

Furthermore, the direct and indirect effects of work motivation and work discipline on interpersonal communication were presented.

Table 7. Direct and Indirect Effects

\begin{tabular}{|l|l|l|l|}
\hline \multirow{2}{*}{\multicolumn{1}{|c|}{ Variable }} & \multicolumn{2}{c|}{ Effect } & \multirow{2}{*}{ Total } \\
\cline { 2 - 3 } & \multicolumn{1}{|c|}{ Direct on $\mathbf{X}_{\mathbf{3}}$} & \multicolumn{1}{c|}{ Indirect } & \\
\hline Work Motivation $\left(\mathrm{X}_{1}\right)$ & 0.209 & 0.063 & 0.272 \\
\hline Work Discipline $\left(\mathrm{X}_{2}\right)$ & 0.186 & 0.066 & 0.252 \\
\hline
\end{tabular}




\section{Total}

0.524

The direct and indirect effects of work motivation, work discipline, and interpersonal communication on teacher performance were displayed as follows.

Table 8. Direct and Indirect Effects

\begin{tabular}{|l|l|l|l|}
\hline \multirow{2}{*}{\multicolumn{1}{c|}{ Variable }} & \multicolumn{2}{c|}{ Effect } & \multirow{2}{*}{ Total } \\
\cline { 2 - 3 } & \multicolumn{1}{c|}{ Direct on $\mathbf{X}_{3}$} & \multicolumn{1}{c|}{ Indirect } & \\
\hline Work Motivation $\left(\mathrm{X}_{1}\right)$ & 0.019 & 0.187 & 0.296 \\
\hline Work Discipline $\left(\mathrm{X}_{2}\right)$ & 0.006 & 0.178 & 0.224 \\
\hline Int. Communication $\left(\mathrm{X}_{3}\right)$ & 0.382 & - & 0.382 \\
\hline
\end{tabular}

Based on data analysis employing the path analysis, the following results are obtained.

1. Based on the test results of the path coefficient, it was found that $\rho_{\mathrm{y} 1}=0.138$. By applying the $t$-test, it showed that $\mathrm{t}_{\text {count }}>\mathrm{t}_{\text {table }}$ or $2.146>1.75$. The result showed that the effect of Work Motivation $\left(\mathrm{X}_{1}\right)$ on Performance $(\mathrm{Y})$ was significant. Thus, it could be stated that work motivation played a role in improving teacher performance.

2. The path coefficient found that $\rho_{\mathrm{y} 2}=0.215$. By using the $t$-test, it showed that $t_{\text {count }}>t_{\text {table, }}$ which was $2.216>1.75$. It indicated that the influence of Work Discipline $\left(\mathrm{X}_{2}\right)$ on Performance (Y) was significant. Therefore, it could be stated that work discipline played a role in enhancing teacher performance.

3. The path coefficient of $\rho_{\mathrm{y} 3}$ was 0.412 . By employing the $t$-test, it showed that $t_{\text {count }}>t_{\text {table, }}$, which was $2.334>1.75$. These findings indicated that the influence of Interpersonal Communication $\left(\mathrm{X}_{3}\right)$ on Performance $(\mathrm{Y})$ was significant. Hence, it could be stated that work motivation played a role in developing teacher performance.

4. The path coefficients obtained from statistics were $\rho_{\mathrm{y} 3}=0.412>\rho_{\mathrm{y} 2}=0.215>\rho_{\mathrm{y} 1}=0.138$, which means that the most primary influence of Teacher Performance was Interpersonal Communication, followed by the Work Discipline factor, and Work Motivation as the least significant factor.

\section{Discussions}

The path coefficient of work motivation on teacher performance was $\rho_{\mathrm{y} 1}=0.138$. The direct influence of work motivation on teacher performance was 0.019 . These results show that work motivation increased teacher performance. Furthermore, the findings of this study support the theory of Usman (2009). He suggested that motivation is the desire in an individual who stimulates them to take action, or motivation is the basis or reason for someone's behavior. This finding also supports Schunk (2011), who argued that motivation could be defined as a desire or need of an individual in doing their work. Work motivation is a driving force in life and works to complete one's responsibility. If work motivation is low, teachers will also be less productive, which leads to a lack of teachers' performance.

The path coefficient of work discipline on teacher performance was $\rho_{\mathrm{y} 2}=0.215$. Furthermore, the direct influence of work discipline on teacher performance was 0.046 . These results indicate that work discipline improved teacher performance. The findings of this study support Barnawi (2012). He found that discipline is active management to encourage members 
of the organization to meet various rules and regulations in an organization, including code of conduct, members' compliance, and sanctions for violators.

Furthermore, the results also support those of Simba positing that discipline had a positive relationship with academic performance in eighth-grade students of the Muhoroni SubCounty Public Elementary School, Kenya. His findings also show that academic performance jumped with increasing levels of discipline. The findings are in line with those of Ehiane, stating that $70 \%$ of respondents believe that school discipline management had an impact on student academic achievement. Discipline influenced student academic achievement. Time management compliance affected student academic achievement. In regards to carrying out daily tasks, if teachers are disciplined in their work, they will not encounter any challenges and will have a positive effect on completing their responsibilities. Due to work discipline, if teachers encounter obstacles, they will be quickly solved. Also, the implications of teacher performance were improved.

The influence of the coefficient of interpersonal communication on teacher performance was $\rho_{\mathrm{y} 3}=0.412$. The direct effect of work discipline on teacher performance was 0.381. The influence of interpersonal communication was the highest compared to motivational and disciplinary factors. These findings prove that interpersonal communication improved teacher performance. The results are in line with the theory proposed by Brent D. Ruben. He explains that human communication is a process through which individuals in relationships, in groups, in organizations, and in society create, transmit, and use the information to coordinate their environment and others. This finding supports Haryaka (2018), who found that interpersonal communication had a direct positive effect on lecturer performance.

Similarly, it supports Navy O'Reilly and Robert's research, which showed a relationship between the quality and quantity of communication with organizational performance. An individual with a high level of interpersonal communication will quickly adjust to the work environment and rapidly associate with others. If teachers can communicate with other teachers in carrying out their professionalism, they will overcome their challenges fast by communicating with other teachers or parties. It then could lead to teacher performance improvement. Based on statistical calculations, the path coefficient from $\mathrm{X} 3$ to $\mathrm{Y}$ is $\rho \mathrm{y} 3=$ 0.412 , the path coefficient from $\mathrm{X} 2$ to $\mathrm{Y}$ is $\rho \mathrm{y} 2=0.215$ and the path coefficient from $\mathrm{X} 1$ to $\mathrm{Y}$ is $\rho y 1=0.138$. This shows that $\rho y 3=0.412>\rho y 2=0.215>\rho y 1=0.138$

Furthermore, it was found that $\rho_{\mathrm{y} 3}=0.412>\rho_{\mathrm{y} 2}=0.215>\rho_{\mathrm{y} 1}=0.138$ by comparing the sequence of path coefficients obtained from statistics. The results indicate that the most primary factor influencing teacher performance was interpersonal communication, followed by the second sequence, work discipline. Also, it was found that the smallest factor was work motivation. This study's findings indicate that although the three variables affected teacher performance, the more dominant effect on teacher performance was the interpersonal communication factor. The results of this study support Navy O'Reilly and Robert's study. They found that interpersonal communication was effective communication, known as one of the bases for the success of an organization. In other words, the most prominent way to achieve organizational goals is by developing interpersonal communication among members of the organization.

\section{Conclusion}

1. Work motivation had a direct positive effect on teacher performance, indicating that high work motivation could increase high teacher performance.

2. Work discipline had a direct positive effect on teacher performance, meaning that high work discipline could raise teacher performance.

3. Interpersonal communication had a direct positive effect on teacher performance, showing that high interpersonal communication could increase teacher performance. 
4. Among the three factors (work motivation, work discipline, and interpersonal communication), the most influential one on teacher performance is interpersonal communication.

\section{Implications}

1. Principals always need to give guidance and motivation to teachers. Hence, it can encourage them to educate their students, prepare their learning tools, properly instruct learning activities. Also, teachers can engage in non-teaching professionalism activities, such as helping with school administration activities, fostering extracurricular activities, and assisting with guidance and counseling. Furthermore, principals should award teachers who perform well in schools, such as awarding them with training or future studies.

2. Schools need to improve excellent service to teachers, students, parents, and the community, especially in managing discipline. It is necessary to enforce disciplinary rules in the school environment to teachers, students, and other education personnel. If a party violates the code of conduct, they should be reprimanded or given sanctions. On the other hand, those who have high discipline should be given awards.

3. To create a conducive environment at schools, it is necessary to provide facilities that support communication between fellow teachers, teachers with principals and other school leaders, teachers with employees and administration, and teachers with school committees. The Internet should also be provided to all school members and cover communication between the school and the community. Thus, interpersonal communication in schools runs smoothly. Also, schools are expected to complement learning facilities in their school environments, such as libraries, laboratories, health clinics, and security facilities.

\section{References}

[1]. Abdul Sukor, 2008. Keadilan Penilaian dalam Kalangan Guru dan Hubungan dengan Motivasi Kerja dan Prestasi Akademik Sekolah. Diunduh 2008, http:// scholar.google.com/scholar.

[2]. Arni, Muhammad, 2011. Komunikasi Organisasi. Jakarta: Bumi Aksara.

[3]. Bachtiar, Doni. Pengaruh Motivasi dan Lingkungan Kerja terhadap Kinerja Karyawan, di unduh 2008. http://www.journal.unnes.ac.id/sju/index.php/maj.

[4]. Barnawi dan Arifin, Mohammad, 2012. Kinerja Guru Profesional, Jogjakarta: Ar-Ruzz Media.

[5]. DeVito,Joseph A., 2011. Komunikasi Antar Manusia. Edisi Kelima. AlihBahasa Agus Maulana. Tangerang Selatan: Karisma Publishing Group.

[6]. Ehiane, O. Stanley, 2014. Discipline and Academic Performance (A Study of Selected Secondary Schools in Lagos, Nigeria). International Journal of Academic Research in Progressive Education and Development, January 2014, Vol 3, No. 1. DOI:10.6007/IJARPED/v3-i1/758. ～URL:http://dx.doi.org/10.6007/IJARPED/v3i1/758.

[7]. Haryaka, U, 2018. The Effect of Emotional, Academic Loyalty, and Interpersonal Communication on Lectures' Performance of Mulawarman University Samarinda. Advances in Intelligent Systems Research (AISR), volume 144. Proceeding of the 2017 International Conference of Education and Technology. Published by Atlantis Press. September 2018. https://creativecommons.org/licences/by-nc/4.0

[8]. Irawan, Rizali, 2013. Hubungan Komunikasi Interpersonal dan Motivasi Kerja dengan Kinerja Pegawai Badan Perpustakaan Provinsi Kalimantan Timur. Samarinda: Tesis.

[9]. Liliweri, Alo, 2014. Komunikasi Antar Personal, Jakarta: Kencana Prenadamedia Group. 
[10]. Maulah D. Rojifah, 2016. Pengaruh Komunikasi Interpersonal Kerja Kepala Sekolah dan Motivasi Kerja Terhadap Kinerja Guru di SMP Swasta Sekecamatan Tandes Kota Surabaya. E- Jurnal UNESA Vol 2. No. 2 (2016)

[11]. Mulyasa, H.E., 2013. Uji Kompetensi dan Penilan Kinerja Guru. Bandung: Remaja Rosdakarya.

[12]. Munawarah, 2013. The Effect of Type STAD Cooperative Learning Model, the Way of Learning, and Learning Motivation toward Entrepreneurial Attitudes. IOSR Journal of Research \& Method in Education (IOSR-JRME) Vol 3 Issue 5 (Nov-Dec. 2013), http://www.iosrjournals.org.

[13]. Riduan, 2015. Metode dan Teknik Menyusun Proposal Penelitian, Bandung: Alfabeta.

[14]. Schunk, H. Dale dkk. 2016. Motivasi dalam Pendidikan, Jakarta: PT Indeks.

[15]. Siburian, P. 2012. Pengaruh Komunikasi Interpersonal, dan Motivasi Berprestasi Terhadap Kepuasan Kerja Guru SMA Parulian 2 Medan. Jurnal Generasi Kampus, Http://www.digilib.unimerd.ac.id

[16]. Simba, O.S, John Odwar Agak, and Eric K. Kabuka, 2016. Impact of Discipline and Academic Performance of Pupils in Public Primary Schools in Muhoroni Sub-County, Kenya. Journal of Education and Practice, Vol.7 No.6, 2016. http://www.iiste.org.

[17]. Suhaimi, Akbar and Sjamsir. H. 2019. The Effect of Pedagogical Competence, Attitude Towards Profession and Motivation on Teachers Performance. First International Conference on Technology and Educational Science. Publisher. EAI. ICTES. https://eudl.eu/doi/10.4108/eai.21-11-2018.2282241

[18]. Sukor, Abdull, 2008. Keadilan penilaian prestasi dalam kalangan guru dan hubungannya dengan motivasi kerja dan prestasi akademik sekolah, di unduh tahun 2008. http: //www.scholar.google.com/scholar.

[19]. Suranto, 2012. Komunikasi Interpersonal, Yogyakarta: Graha Ilmu.

[20]. Susanto, Ahmad, 2016. Manajemen Peningkatan Kinerja Guru, Jakarta: Prenadamedia.

[21]. Tanpa Pengarang. 2009. Undang-Undang RI Nomor 14 Tahun 2005 tentang Guru dan Dosen. Bandung: Citra Umbara.

[22]. Uno B, Hamzah dan Lamatenggo, Nina, 2014. Teori Kinerja dan Pengukurannya. Jakarta: PT Bumi Aksara.

[23]. Usman, Husaini, 2009. Manajemen Teori, Praktik dan Rised Pendidikan, Jakarta: Bumi Aksara. https://www.researchgate.net/publication/341526704

[24]. Wardan, Khusnul, 2011. Motivasi Kerja Guru. Yogyakarta: Interpena.

[25]. Wibowo, 2007. Manajemen Kinerja, Jakarta: Raja Grafindo Pustaka. 